\title{
Dragonflies Caught by Plants (Odonata: Libellulidae)
}

\author{
Antonio Torralba-Burrial \& Francisco J Ocharan
}

Received: 2006-10-13

Accepted: 2006-12-04

Torralba-Burrial A \& Ocharan F J [Dpto Biol Organ Sist, Univ Oviedo, E-33071, Oviedo, España]: Dragonflies Caught by Plants (Odonata: Libellulidae). -Entomol Gener 30 (4): 301-305, Stuttgart 2007-12.

[Note]

Observations of a male of Crocothemis erythraea (Brullé 1832) which was caught by the plant Silene inaperta (Caryophyllales: Caryophyllaceae) are reported. This plant presents sticky secretions on the stem, with seemingly defensive functions against herbivory. The dragonfly was caught when sticking the four wings to the stems of several plants. Other cases of capture of dragonflies by non insectivorous plants are reviewed.

Key words: Crocothemis erythraea (Brullé 1832) - Silene inaperta - Caryophyllaceae - defenses plants-insects relations

Torralba-Burrial A \& Ocharan F J [Dpto Biol Organ Sist, Univ Oviedo, E-33071, Oviedo, España]: Libélulas Atrapadas por Plantas (Odonata: Libellulidae). - Entomol Gener 30 (4): 301-305; Stuttgart 2007-12.

[Nota]

Se describen observaciones de un macho de Crocothemis erythraea (Brullé 1832) capturado por la planta Silene inaperta (Caryophyllales: Caryophyllaceae). Esta planta presenta secreciones pegajosas sobre el tallo, las cuales parecen tener funciones defensivas contra la herbivoría. La libélula fue capturada al quedar pegadas sus cuatro alas a varias plantas. Otros casos de capturas de libélulas por parte de plantas no insectívoras son revisados.

Palabras clave: Crocothemis erythraea (Brullé 1832) - Silene inaperta - Caryophyllaceae - defensas - relaciones planta-insecto

\section{Introduction}

Interactions between plants and insects are varied, including: (1) feeding (mostly insects that feed of plants or parts of plants, but also plants that feed partially of insects), (2) transport (plants or their parts - pollen, seeds... - dispersed by insects, in few cases the other way round) and (3) refuge. Depending on the concrete relation, their members can obtain a benefit, a damage or nothing, being possible all the combinations of those results for both members. To avoid, or at least to limit the harmful effects for the plants, many plants have developed a series of physical (spines, sclerophyllous tissues, ...), and chemical (poison, sticky substances, ...) defenses against a very large suite of enemies, including insects and other animals. In the same way, many plants have developed a broad series of structures and mechanisms to facilitate the relationships of positive effects for the plants. 